Old Dominion University

ODU Digital Commons

Bioelectrics Publications

Frank Reidy Research Center for Bioelectrics

$1-2018$

\title{
Production and Correlation of Reactive Oxygen and Nitrogen Species in Gas- and Liquid-Phase Generated by Helium Plasma Jets Under Different Pulse Widths
}

Zhijie Liu

ChunxiZhou

Dingxin Liu

Dehui Xu

Wenjie Xia

See next page for additional authors

Follow this and additional works at: https://digitalcommons.odu.edu/bioelectrics_pubs

Part of the Fluid Dynamics Commons, and the Plasma and Beam Physics Commons

\section{Repository Citation}

Liu, Zhijie; Zhou, Chunxi; Liu, Dingxin; Xu, Dehui; Xia, Wenjie; Cui, Qingjie; Wang, Bingchuan; and Kong, Michael G., "Production and Correlation of Reactive Oxygen and Nitrogen Species in Gas- and Liquid-Phase Generated by Helium Plasma Jets Under Different Pulse Widths" (2018). Bioelectrics Publications. 147.

https://digitalcommons.odu.edu/bioelectrics_pubs/147

\section{Original Publication Citation}

Liu, Z., Zhou, C., Liu, D., Xu, D., Xia, W., Cui, Q. ... Kong, M. G. (2018). Production and correlation of reactive oxygen and nitrogen species in gas- and liquid-phase generated by helium plasma jets under different pulse widths. Physics of Plasmas, 25(1), 013528. doi:10.1063/1.4999520 
Authors

Zhijie Liu, Chunxi Zhou, Dingxin Liu, Dehui Xu, Wenjie Xia, Qingjie Cui, Bingchuan Wang, and Michael G. Kong 


\section{Production and correlation of reactive oxygen and nitrogen species in gas- and liquid- phase generated by helium plasma jets under different pulse widths}

Zhijie Liu, Chunxi Zhou, Dingxin Liu, Dehui Xu, Wenjie Xia, Qingjie Cui, Bingchuan Wang, and Michael G Kong

Citation: Physics of Plasmas 25, 013528 (2018); doi: 10.1063/1.4999520

View online: https://doi.org/10.1063/1.4999520

View Table of Contents: http://aip.scitation.org/toc/php/25/1

Published by the American Institute of Physics

\section{Articles you may be interested in}

Comparison between the water activation effects by pulsed and sinusoidal helium plasma jets

Physics of Plasmas 25, 013520 (2018); 10.1063/1.5016510

Fluid modeling of radical species generation mechanism in dense methane-air mixture streamer discharge Physics of Plasmas 25, 013519 (2018); 10.1063/1.5016855

Control of radial propagation and polarity in a plasma jet in surrounding $\mathrm{Ar}$

Physics of Plasmas 25, 013505 (2018); 10.1063/1.5010993

Influence of driving frequency on discharge modes in the dielectric barrier discharge excited by a triangle voltage

Physics of Plasmas 25, 013512 (2018); 10.1063/1.4998615

Perspective: The physics, diagnostics, and applications of atmospheric pressure low temperature plasma sources used in plasma medicine

Journal of Applied Physics 122, 020901 (2017); 10.1063/1.4993710

Discharge mode transition and temporal-spatial evolution of an air-water plasma jet generated by pulsating DC power

Physics of Plasmas 24, 123515 (2017); 10.1063/1.5008487

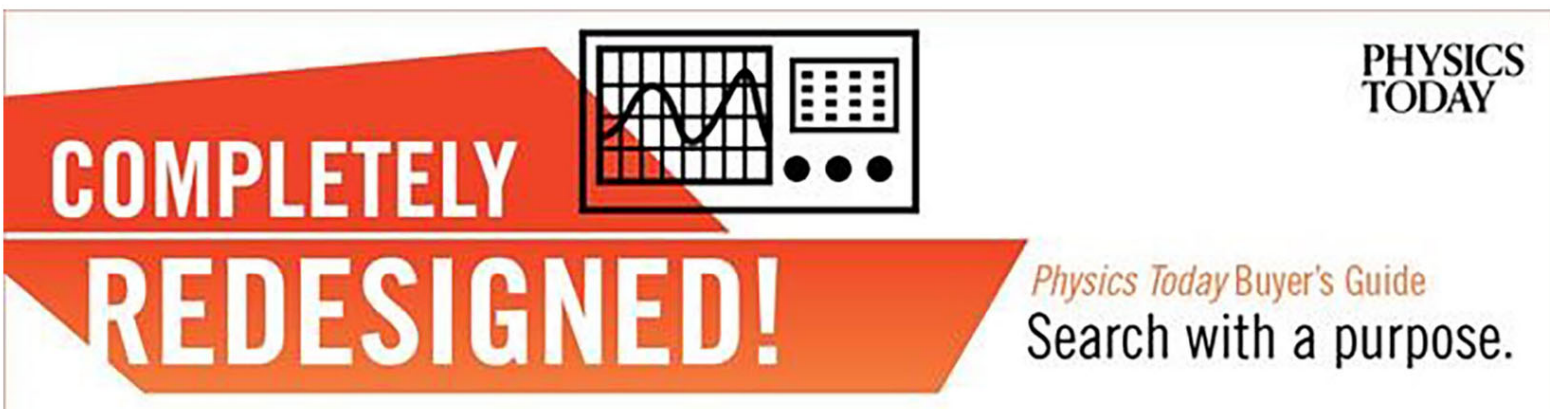




\title{
Production and correlation of reactive oxygen and nitrogen species in gas- and liquid-phase generated by helium plasma jets under different pulse widths
}

\author{
Zhijie Liu, ${ }^{1, a)}$ Chunxi Zhou, ${ }^{1}$ Dingxin Liu, ${ }^{1}$ Dehui Xu, ${ }^{1}$ Wenjie Xia, ${ }^{1}$ Qingjie Cui, ${ }^{1}$ \\ Bingchuan Wang, ${ }^{1}$ and Michael G Kong ${ }^{1,2,3, a)}$ \\ ${ }^{1}$ State Key Laboratory of Electrical Insulation and Power Equipment, Centre for Plasma Biomedicine, \\ School of Electrical Engineering, Xi' an Jiaotong University, Xi' an, Shaanxi 710049, \\ People's Republic of China \\ ${ }^{2}$ Frank Reidy Center for Bioelectrics, Old Dominion University, Norfolk, Virginia 23508, USA \\ ${ }^{3}$ Department of Electrical and Computer Engineering, Old Dominion University, Norfolk, \\ Virginia 23529, USA
}

(Received 9 August 2017; accepted 13 January 2018; published online 25 January 2018)

\begin{abstract}
In this paper, we present the effects of the pulse width (PW) on the plasma jet's discharge characteristics, particularly focusing on the production and correlation of the reactive oxygen and nitrogen species (RONS) in gas- and liquid-phase. It is found that the length of plasma jet plume first increases before the PW of $10 \mu \mathrm{s}$, then gradually decreases and finally almost remains unchanged beyond $150 \mu \mathrm{s}$. The plasma bullet disappears after the falling edge of the voltage pulse at low PW, while it terminates far ahead of the falling edge of voltage pulse at high PW. This is mainly attributed to accumulation of space charges that lead to weakening of the reduced electric field with an increase of PW from low to high. More important, it is found that the excited reactive species, the positive and negative ions from plasma jet, and the concentrations of $\mathrm{NO}_{2}{ }^{-}$and $\mathrm{NO}_{3}{ }^{-}$ in deionized water exposed to plasma jet also display the first increasing and then decreasing change trend with increase of PW, while the concentration of $\mathrm{H}_{2} \mathrm{O}_{2}$ in water almost displays the linearly increasing trend. This mainly results from the formation of the $\mathrm{H}_{3} \mathrm{O}^{+}$and $\mathrm{HO}_{2}{ }^{-}$, as well as their ion water clusters that can produce more $\mathrm{OH}$ radicals to be converted into $\mathrm{H}_{2} \mathrm{O}_{2}$, while the $\mathrm{NO}_{2}{ }^{-}$and $\mathrm{NO}_{3}{ }^{-}$in gas phase can transport into water and exist most stably in water. The water cluster formation at gas-liquid interface is an important key process that can affect the chemical nature and dose of aqueous RONS in water; this is beneficial for understanding how the RONS are formed in liquid-phase. Published by AIP Publishing. https://doi.org/10.1063/1.4999520
\end{abstract}

\section{INTRODUCTION}

Atmospheric pressure plasma jets (APPJs) have recently attracted considerable interest as an efficient source of highly reactive species for applications in materials processing and biological medicine. ${ }^{1-4}$ As we know, the APPJs generate long plasma plumes (about $10 \mathrm{~cm}$ ) in open space rather than in confined discharge gaps, which make it possible for direct treatments, and have no limitation on the size and shape of the treated objects. ${ }^{5,6}$ Additionally, the APPJs have a relatively high electron temperature and a low gas temperature, and high energy electrons can produce chemically rich gasphase environments with reactive oxygen and nitrogen species (RONS), which are very important for applications such as plasma medicine. ${ }^{7,8}$ However, the control of chemical reactions and the production of RONS in the plasma jet are difficult because the discharge is very unstable and easily transforms to filamentary discharge when the operating conditions are slightly changed; the filamentary discharge would lead to lethal danger to the living tissue due to the high current and local gas heating. 9,10 Therefore, it is essential to regulate and control the discharge parameters to investigate the

\footnotetext{
a) Authors to whom correspondence should be addressed: liuzhijie2010@ 163.com andmglin5g@gmail.com
}

discharge characteristics and modes of the plasma jet for the biomedical applications.

Our interest has been focused on regulating and controlling the plasma jet though the parameters of pulse voltage. Pulse width $(\mathrm{PW})$ is one of the important parameters, and it can be used to control the discharge characteristics such as plasma jet length and plasma bullet propagation. Up to now, some works about the effect of PW on plasma jet characteristics have been reported by some groups. ${ }^{11-17}$ Walsh et al. reported the impact of PW on the propagation velocity of the ionization front and found that the maximum discharge length occurs under PW of $3 \mu \mathrm{s} .{ }^{13} \mathrm{Lu}$ et al. investigated that the effects of PW on the propagation of plasma bullets in a pulsed plasma jet and found that, as PW increases up to $100 \mu \mathrm{s}$, the bullet propagates out from the nozzle with longer delay time. When the PW is increased to more than $100 \mu \mathrm{s}$, the delay time of the bullet propagating out from the nozzle becomes much shorter. ${ }^{14,15}$ Uchida et al. clarified the effect of the voltage duty ratio on the production of reactive $\mathrm{O}$ atoms at a driving voltage frequency of $5 \mathrm{kHz} .{ }^{17}$ Even though some diagnostic studies under different PWs have been conducted and the corresponding physical mechanism has been fully discussed and confirmed, these studies only focused on the propagation of plasma bullets in open air and 
the reports about the influence of PW on the production of RONS in gas- and liquid-phase have not yet been performed. In particular, the correlation of RONS between gas- and liquid-phase is still largely unknown. Understanding the source of reactive species in the liquid phase possesses profound and important significance in the subsequent biomedical applications, such as bacteria inactivation and cancer cell destruction. $^{1-7,18-20}$

The main purpose of this study is to clarify the effects of the PW on the plasma jet's discharge characteristics, with particular focus on the production of the RONS in gas- and liquid-phase, which are desirable for biological medicine applications. For this purpose, we diagnosed the RONS by optical emission spectroscopy (OES), molecular beam mass spectrometer (MBMS), and microplate reader to analyze the correlation of RONS, transported from gas phase into liquid phase.

\section{EXPERIMENTAL SETUP}

Figure 1(a) shows a schematic illustration of the experimental setup of plasma jet source, which is made up of a coaxial needle-to-ring electrode configuration, of which the needle is a tungsten needle with a length of $10 \mathrm{~cm}$ and a diameter of $0.1 \mathrm{~mm}$, and is connected to a high voltage pulse supply. The ring is a copper sheet of a length of $10 \mathrm{~mm}$, located $10 \mathrm{~mm}$ from the open end of quartz tube (od.: $6 \mathrm{~mm}$, id.: $4 \mathrm{~mm}$ ), and serves as the grounded electrode. The needle electrode is covered by an insulating dielectric material (quartz glass) with a length of $50 \mathrm{~mm}$ (od.: $2 \mathrm{~mm}$, id.: $1 \mathrm{~mm}$ ) to make the plasma plume more diffuse and stable in the quartz tube. Helium $(\mathrm{He})$ with high purity $(5 \mathrm{~N})$ is controlled by a mass flow controller into the tube from gas inlet at a rate of $3 \mathrm{~L} / \mathrm{min}$. A homemade pulse generator with a rising time of approximate $40 \mathrm{~ns}$ is used to generate the plasma jet, and the PW is adjustable according to fixed value of pulse rate. The pulse voltage and pulse rate are fixed at $8 \mathrm{kV}$ and
$4 \mathrm{kHz}$ in this study. The corresponding PW can be adjusted from $0.5 \mu$ s to $200 \mu \mathrm{s}$. The electrical characteristics are measured by a digital oscilloscope equipped with voltage/current probes (P6015A and P6021, Tektronix), and the OES is detected by an Andor SR-750i grating monochromator (grating grooving 1200 lines/mm). Photographs of the plasma plumes are taken by a camera(Nikon D7000) with an exposure time of $1 \mathrm{~s}$, and time evolution of APPJ plume are obtained by an ICCD camera (PI-MAX3, Princeton Instruments) with an exposure time of $5 \mathrm{~ns}$. A molecular beam mass spectrometer (MBMS, Hiden Analytical, Ltd.) system is used for detecting positively and negatively charged species in the He plasma jet. A Petri dish filled deionized water of $5 \mathrm{~mL}$ is put underneath the plasma jet for studying the plasma-liquid interaction, the distance between the tube nozzle and the face of water is $10 \mathrm{~mm}$, and the some long-lived aqueous reactive species such as $\mathrm{H}_{2} \mathrm{O}_{2}, \mathrm{NO}_{2}{ }^{-}$, and $\mathrm{NO}_{3}{ }^{-}$are generated in water. The measured methods of the concentrations of aqueous $\mathrm{H}_{2} \mathrm{O}_{2}, \mathrm{NO}_{2}{ }^{-}$, and $\mathrm{NO}_{3}{ }^{-}$can been found in previous reports. ${ }^{7,21,22}$

\section{RESULTS AND DISCUSSION}

\section{A. The discharge characteristics}

The images of the plasma jet plume are displayed in Fig. 1(b) for different PWs from $0.5 \mu \mathrm{s}$ to $200 \mu \mathrm{s}$. It is found that the length of plasma jet plume first increases before the PW of $10 \mu \mathrm{s}$, after that gradually decreases, and finally becomes almost unchanged after the PW of $150 \mu \mathrm{s}$. When the PW is longer than $10 \mu \mathrm{s}$, the controlling of PW does not affect the length of plasma jet plume. The change of plasma jet length is mainly attributed to more energy injection leading to stronger space electric field with increase of PW before $10 \mu \mathrm{s}$, so the plasma jet plume has a longer length. Further increasing PW can significantly increase the accumulation of the space charges on the tube wall to cause the formation of reverse electric field. This will weaken the reduced electric (a)

(a) Pulse supply

(b)

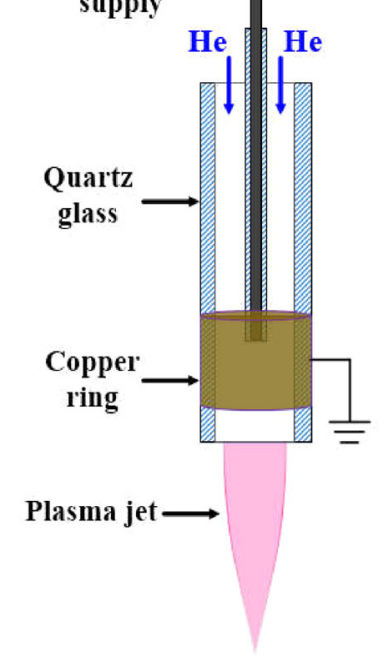

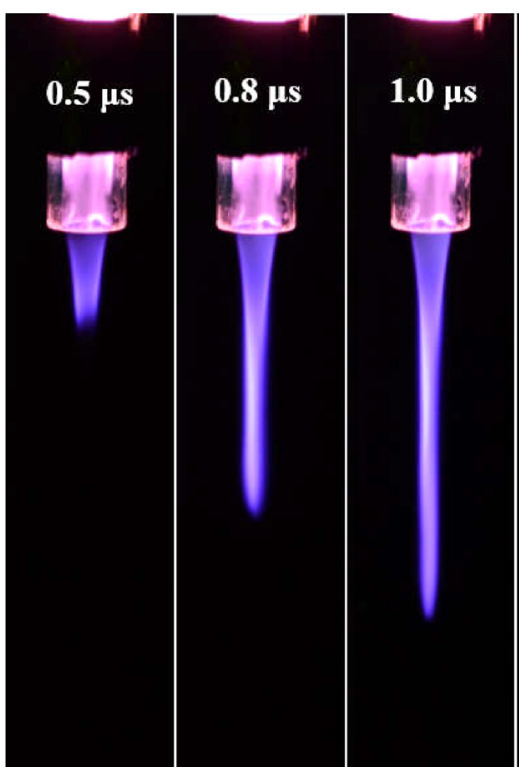
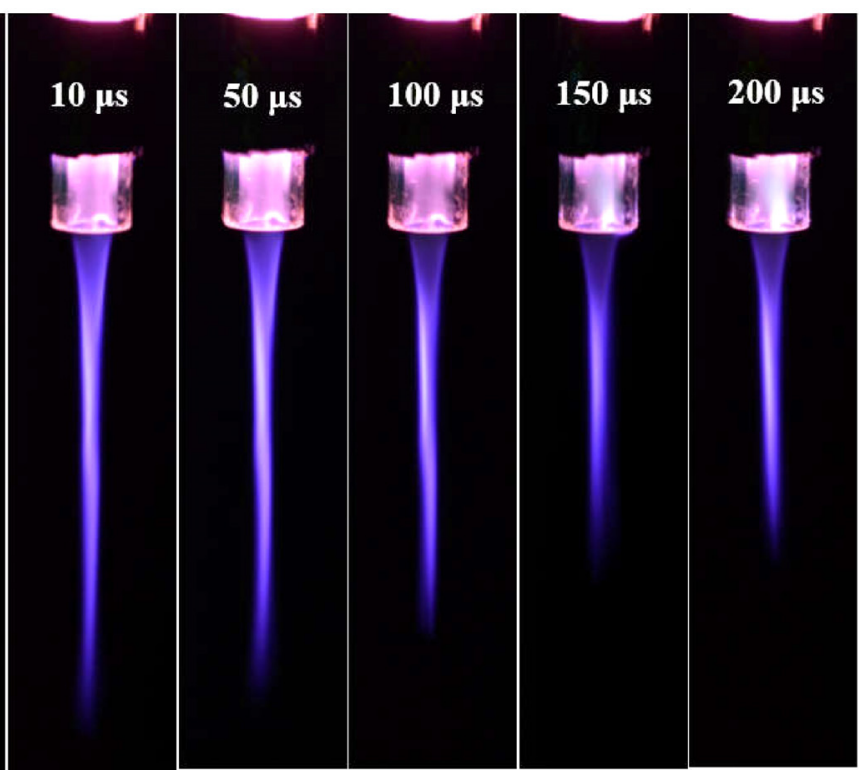

FIG. 1. (a) The schematic illustration of the experimental setup of plasma jet and (b) the images of plasma jet under different PWs at the pulse voltage of $8 \mathrm{kV}$, the pulse rate of $4 \mathrm{kHz}$, and the flow rate of $3 \mathrm{~L} / \mathrm{min}$. 

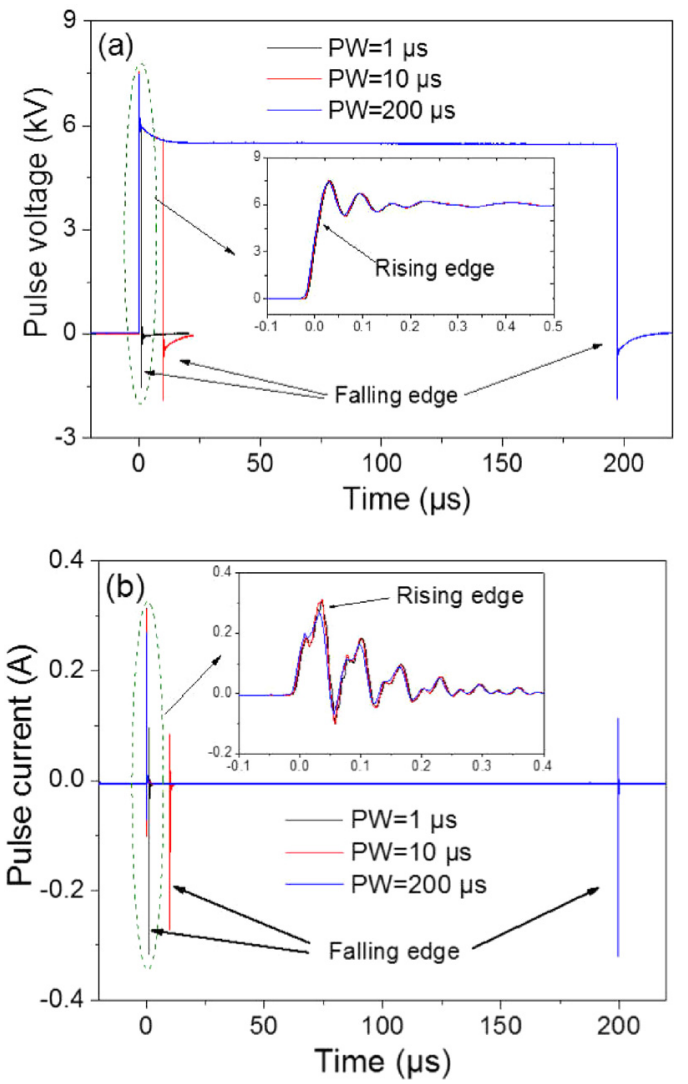

FIG. 2. The waveforms of (a) pulse voltage and (b) current of the plasma jet under different PWs of $1 \mu \mathrm{s}, 10 \mu \mathrm{s}$, and $200 \mu \mathrm{s}$.

field in a discharge region, resulting in a shorter length of plasma jet plume compared to the length at PW of $10 \mu \mathrm{s} .{ }^{15,23}$

The typical waveforms of pulse voltage and current of the plasma jet are shown in Figs. 2(a) and 2(b) under PW of $1 \mu \mathrm{s}, 10 \mu \mathrm{s}$, and $200 \mu \mathrm{s}$, respectively. It can be seen that the waveforms of pulse voltage at the rising edge almost overlap with each other. Except for their different PWs, the falling edge does as well. This implies that any change of the plasma jet plume is only caused by the PW, not by the other parameters of the pulse voltage supply. Additionally, it is also found that the waveforms of pulse current through the grounded electrode has a positive pulse at the rise-edge of the voltage and a negative pulse at the fall-edge of the voltage. It is indicated that the plasma jet is only produced during the rise-edge and fall-edge phases as evidenced by the current peaks, similar to those reported pulse-excited discharges as a result of the reverse breakdown. ${ }^{23,24}$

To image the plasma jet plume on a nanosecond scale, the time-resolved images of the plasma jet under PW of $1 \mu \mathrm{s}$, $10 \mu \mathrm{s}$, and $200 \mu \mathrm{s}$ are taken by ICCD camera and are shown in Fig. 3. The time of single pulse cycle (as shown in Fig. 2) is utilized to analyze the evolution behaviors of the plasma jet. It is found that the discharge behaviors for each PW of $1 \mu \mathrm{s}, 10 \mu \mathrm{s}$, and $200 \mu \mathrm{s}$ display plasma bullets, which start from initial breakdown within the tube and then propagate into the open air. Furthermore, as Figs. 3(a)-3(c) are compared with each other, the size of plasma bullet first increases, reaches the maximum size, then gradually decreases, and finally becomes smaller and darker until disappears as it propagates. For $\mathrm{PW}=1 \mu \mathrm{s}$, the plasma bullet disappears after the falling edge of the voltage pulse; however, for $\mathrm{PW}=10 \mu \mathrm{s}$ and $200 \mu \mathrm{s}$, it is found that plasma bullet terminates far ahead of the falling edge of voltage pulse. Meanwhile, the existence of the plasma bullet for the $\mathrm{PW}=10 \mu \mathrm{s}$ starts from $0.74 \mu$ s to $2.34 \mu \mathrm{s}$ and the interval is about $1.6 \mu \mathrm{s}$, which is significantly longer than the other cases (the $0.8 \mu \mathrm{s}$ for $\mathrm{PW}=1 \mu \mathrm{s}$, the 1.1 $\mu \mathrm{s}$ for $\mathrm{PW}=200 \mu \mathrm{s}$ ), indicating that the duration of plasma bullet for the $\mathrm{PW}=10 \mu$ s propagating in open air is the longest among of the three kinds of plasma jets. This may be explained by the accumulation of surface charge on the wall of tube; at the low $\mathrm{PW}(\mathrm{PW}<10 \mu \mathrm{s})$, the positive charges in the pulse cycle that propagates to the ground electrode will induce a polarization of the wall of tube, leading to the charges being deposited and forming the reverse electric field. ${ }^{14,15}$ When the PW is increased from $0.5 \mu$ s to $10 \mu \mathrm{s}$, the more and more energy is input to the discharge system, and it leads to the higher reduced electric field and electron density produced in the discharge region. Correspondingly, more penning ionization takes place between the metastable $\mathrm{He}$ and the air molecules, and a longer plasma jet plume is produced. ${ }^{14-17}$

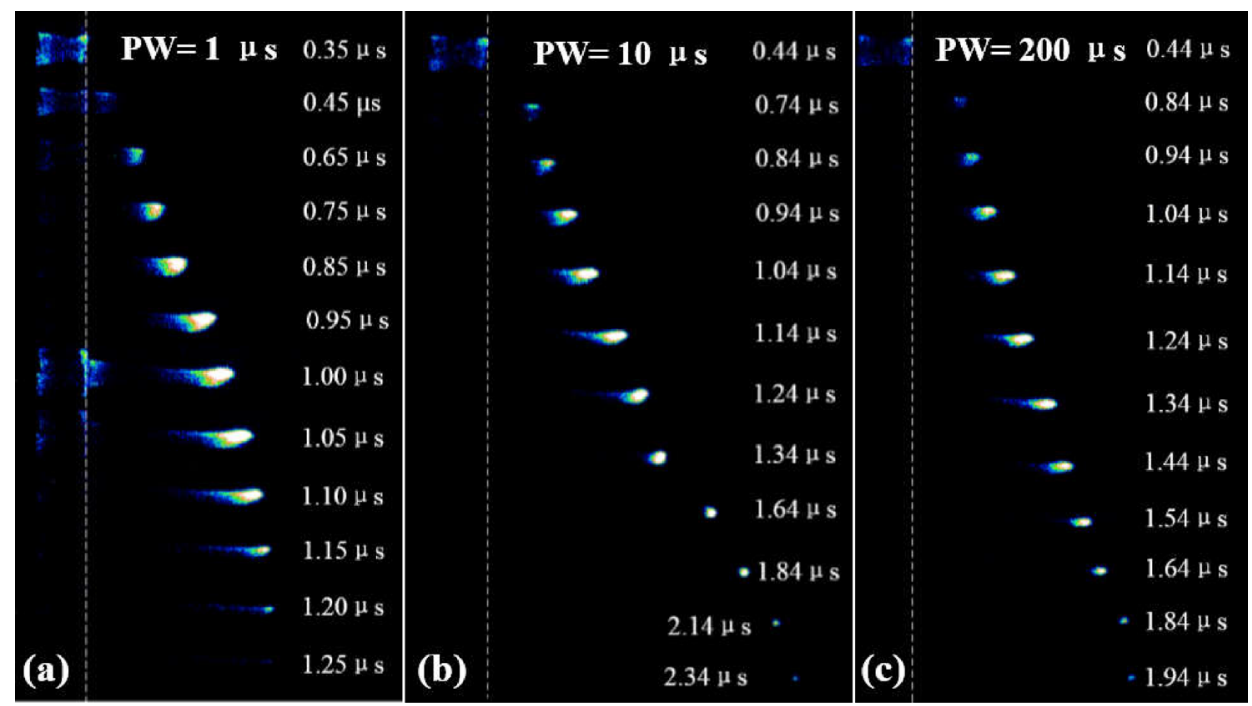

FIG. 3. The time-resolved images of the plasma jet under PW of $1 \mu \mathrm{s}, 10 \mu \mathrm{s}$, and $200 \mu$ s, respectively. 
However, continual increase of the PW $(\mathrm{PW}>10 \mu \mathrm{s})$, on one hand, indicates the decrease in the voltage-off duration (pulse repetition rate of $4 \mathrm{kHz}$ and pulse-cycle of 250 $\mu \mathrm{s})$, and on the other hand, the energy input from pulse supply is not growing. The accumulated charged particles will perform a slow decay of electron-ion and ion-ion recombination in shorter voltage-off duration. The positive space charges are still deposited on the tube surface during the longer discharge duration. ${ }^{14}$ These factors result in the reverse electric field increasing, and the reduced electric field is decreasing in the discharge region. So the appearance of the plasma bullet is delayed as shown in Fig. 3; the length of plasma jet plume and the size of the plasma bullets are becoming shorter and smaller until the accumulation of surface charges on the glass tube surface reach a saturated state.

\section{B. The production of RONS in plasma jet}

To identify and compare the reactive species from the plasma jet under different PWs, the OES in the wavelength range from $300 \mathrm{~nm}$ to $800 \mathrm{~nm}$ is shown in Fig. 4 at PW of $10 \mu \mathrm{s}$ and $200 \mu \mathrm{s}$, respectively; the head of optical fiber is placed vertically to the axis of the tube at nozzle. From Fig. 4 , it can be found that the emission spectra is mainly dominated by $\mathrm{OH}(\mathrm{A}), \mathrm{N}_{2}{ }^{+}(\mathrm{B}), \mathrm{He}\left(3 \mathrm{~s}^{3} \mathrm{~S}\right)$, and $\mathrm{O}\left(3 \mathrm{p}^{5} \mathrm{P}\right)$ emissions; these reactive species produced are attributed to not only high energy electron excitation but also energy transfer from metastable $\mathrm{He}^{25}$ Additionally, these emission lines are almost the same for the plasma jets at PWs of $10 \mu \mathrm{s}$ and $200 \mu \mathrm{s}$, while the emission intensity at PW of $10 \mu \mathrm{s}$ is higher than that at PW of $200 \mu \mathrm{s}$. The similarity of emission lines indicates that these two kinds of plasma jets have similar ability to produce reactive species such as $\mathrm{OH}$ despite the different PW; the dissimilarity of emission intensity suggests that the plasma jet at PW of $10 \mu \mathrm{s}$ has a higher value of reduced electric flied and can produce much greater concentration of reactive species on the tube nozzle. It also confirms the above analysis and explanation about the effect of the PW on the length of plasma jet plume in Fig. 1(b). In order to study the effect of PW on the concentration of reactive species when the PW is increased from $0.5 \mu \mathrm{s}$ to $200 \mu \mathrm{s}$, the

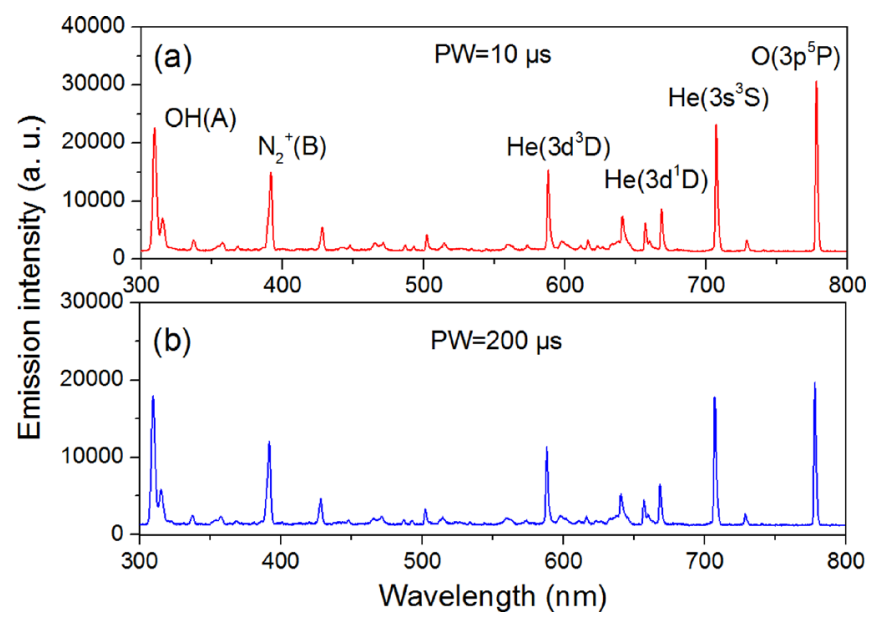

FIG. 4. The OES from the plasma jet at PW of $10 \mu \mathrm{s}$ and $200 \mu \mathrm{s}$, respectively.
OES of reactive species $\mathrm{OH}(\mathrm{A}), \mathrm{N}_{2}{ }^{+}(\mathrm{B}), \mathrm{He}\left(3 \mathrm{~s}^{3} \mathrm{~S}\right)$, and $\mathrm{O}\left(3 \mathrm{p}^{5} \mathrm{P}\right)$ from plasma jet at the exit of quartz tube are diagnosed at different PWs. The emission intensity of these species varying as a function of the PW is shown in Fig. 5. It is found that the emission intensity of $\mathrm{OH}(\mathrm{A}), \mathrm{N}_{2}{ }^{+}(\mathrm{B})$, $\mathrm{He}\left(3 \mathrm{~s}^{3} \mathrm{~S}\right)$, and $\mathrm{O}\left(3 \mathrm{p}^{5} \mathrm{P}\right)$ first increases rapidly when the PW increases from $0.5 \mu \mathrm{s}$ to $10 \mu \mathrm{s}$, and then decreases gradually with the increase of PW from $10 \mu$ s to $200 \mu$ s. The highest peak value for each is at $10 \mu \mathrm{s}$.

It is well known that when living tissues or cells are exposed to APPJs, the interactions between the reactive species and living tissues are believed to trigger a complex chain of biological reactions. Among the reactive species, the positive and negative ions also play an important role in biological medicine application. In our experiment, the molecular beam mass spectrometer is used for detecting the concentrations of positive and negative ions in He plasma jet. The instrument has a three-stage differentially pumped inlet system separated by aligned skimmer cones and pumps. Using the time-averaged intensities (counts/s), in the range 0-70 atomic mass units (amu), the positive and negative ions emanating from the plasma jets are identified. Figure 6 shows the time-averaged mass spectra of positive and negative ions from He plasma jet at PW of $10 \mu \mathrm{s}$. The plasma jet plume and sampling orifice are $15 \mathrm{~mm}$ apart. The assignment of mass spectrum peak for the $\mathrm{m} / \mathrm{z}$ is also given in Fig. 6. It is found that nearly all peaks have been assigned except for the positive ions peak at $\mathrm{m} / \mathrm{z}=17$ and the negative ions peaks at $\mathrm{m} / \mathrm{z}=19,31$, and 39 , which may arise from some impurities. The positive and the negative ions mainly consist of $\mathrm{N}^{+}(\mathrm{m} / \mathrm{z}=14), \mathrm{O}^{+}(\mathrm{m} / \mathrm{z}=16), \mathrm{N}_{2}{ }^{+}(\mathrm{m} / \mathrm{z}=28), \mathrm{O}_{2}{ }^{+}(\mathrm{m} / \mathrm{z}$ =32), $\quad \mathrm{OH}^{-}(\mathrm{m} / \mathrm{z}=17), \quad \mathrm{O}_{2}^{-}(\mathrm{m} / \mathrm{z}=32), \quad \mathrm{NO}_{2}{ }^{-}(\mathrm{m} / \mathrm{z}=46)$, $\mathrm{O}_{3}{ }^{-}(\mathrm{m} / \mathrm{z}=48)$, and $\mathrm{NO}_{3}{ }^{-}(\mathrm{m} / \mathrm{z}=62)$, the general composition of ions is consistent with that of Bruggeman et $a .^{26}$ As reported in Refs. 26-29, the $\mathrm{He}^{+}$ions are produced inside the main discharge via electron neutral ionization process $\left(e^{-}+\mathrm{He} \rightarrow 2 e^{-}+\mathrm{He}^{+}\right)$. Major secondary ions (such as $\mathrm{N}_{2}{ }^{+}$and $\mathrm{O}_{2}{ }^{+}$) in He plasma jet are mainly generated from direct electron impact ionization of air, penning ionization of $\mathrm{N}_{2}$ by metastable $\mathrm{He}$ and charge exchange reactions of $\mathrm{He}^{+}$and

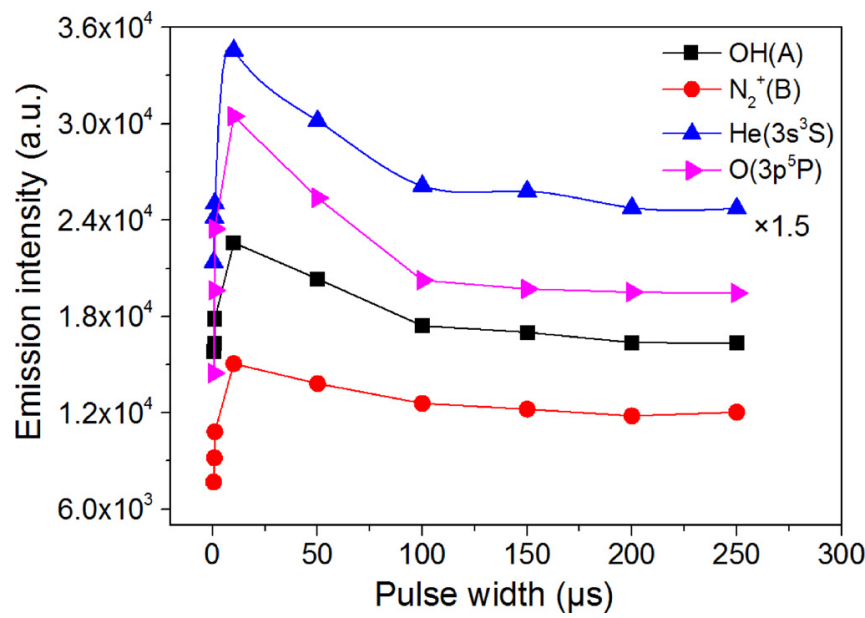

FIG. 5. The emission intensity of $\mathrm{OH}(\mathrm{A}), \mathrm{N}_{2}{ }^{+}(\mathrm{B}), \mathrm{He}\left(3 \mathrm{~s}^{3} \mathrm{~S}\right)$, and $\mathrm{O}\left(3 \mathrm{p}^{5} \mathrm{P}\right)$ produced by plasma jet varies as a function of the $\mathrm{PW}$. 


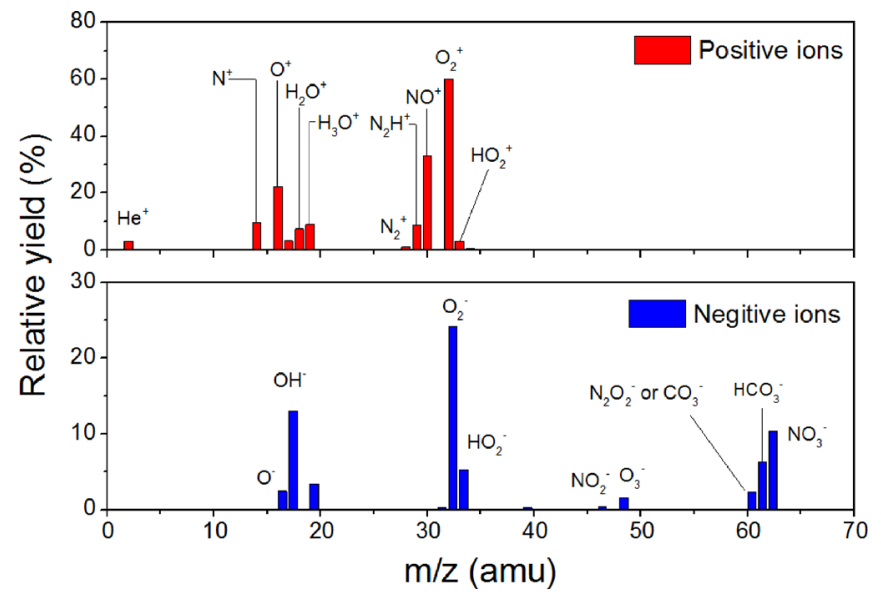

FIG. 6. The mass spectra of positive and negative ions from He plasma jet at PW of $10 \mu$ s measured in the outflow of the plasma jet at a distance of $15 \mathrm{~mm}$ from the gas nozzle.

$\mathrm{He}_{2}{ }^{+}$with $\mathrm{N}_{2}$ and $\mathrm{O}_{2} \cdot{ }^{27,30}$ A large number of negative ions are obtained through the dissociative electron attachment $\left(e^{-}+\mathrm{AB} \rightarrow \mathrm{A}^{-}+\mathrm{B}\right)$ and further attachment process $\left(\mathrm{A}^{-}+M\right.$ $\left.\rightarrow \mathrm{A}^{-} M\right)$, where $M$ denotes molecules in air. ${ }^{26,27}$ Additionally, there are $\mathrm{HO}_{2}{ }^{-}$signals detected by mass spectrometry; it means that $\mathrm{O}_{3}{ }^{-}$and $\mathrm{O}_{2}{ }^{-}$ions may be converted to $\mathrm{HO}_{2}{ }^{-}$ions inside of this system. ${ }^{31}$ And the peak of negative ion at $m / z=60$ may be assigned to $\mathrm{CO}_{3}{ }^{-}$or $\mathrm{N}_{2} \mathrm{O}_{2}{ }^{-28}$

As reported in Refs. 26-33, among all positive ions generated by plasma jets in ambient air, hydronium ions $\left(\mathrm{H}_{3} \mathrm{O}^{+}\right)$are the dominant ions which reproduce to form water clusters. The positive ions generated by plasma jets would transfer their charges to hydronium ions if water molecules were abundant, such as in humid air or into water. Similarly, all negative ions generated by the plasma jets in ambient air, such as $\mathrm{OH}^{-}$, $\mathrm{HO}_{2}{ }^{-}, \mathrm{NO}_{2}{ }^{-}$, and $\mathrm{NO}_{3}{ }^{-}$, would form water clusters stably. ${ }^{26,27}$ For example, when the plasma jet is applied to a water surface, the density of water molecules is typically high near the water surface, and ion water clusters are formed. Furthermore, such water clusters are likely to dissolve directly into water to form the aqueous reactive species such as $\mathrm{H}_{2} \mathrm{O}_{2}, \mathrm{NO}_{3}{ }^{-}$, and $\mathrm{NO}_{2}{ }^{-}$ when they reach the water surface. ${ }^{34}$

Figures 7(a) and 7(b) show the dependence of the PW on the relative yield of positive ions $\left(\mathrm{N}^{+}, \mathrm{O}^{+}, \mathrm{N}_{2}{ }^{+}, \mathrm{O}_{2}{ }^{+}\right)$and negative ions $\left(\mathrm{OH}^{-}, \mathrm{O}_{2}^{-}, \mathrm{NO}_{2}{ }^{-}, \mathrm{NO}_{3}{ }^{-}\right)$, respectively. It is found that the relative yield of both positive ions and negative ions increase up to a maximum value at about $10 \mu \mathrm{s}$ and gradually decrease for higher PW. The increase of relative yield with rising PW may be mainly ascribed to the increase of more energy input from the pulse voltage supply into the discharge region leading to a higher reduced electric field applied. However, when the PW is beyond to $10 \mu \mathrm{s}$, the number density of positive and negative ions begins to decrease because the more charges accumulated on the wall of a glass tube that form the reverse electric field result in the decrease of reduced electric field in gas gap.

\section{The aqueous RONS production}

As we know, APPJs contain a rich mixture of RONS, some of which include $\mathrm{OH}, \mathrm{O}_{2}^{-}, \mathrm{H}_{2} \mathrm{O}_{2}, \mathrm{NO}_{2}{ }^{-}$, and $\mathrm{NO}_{3}{ }^{-}$;
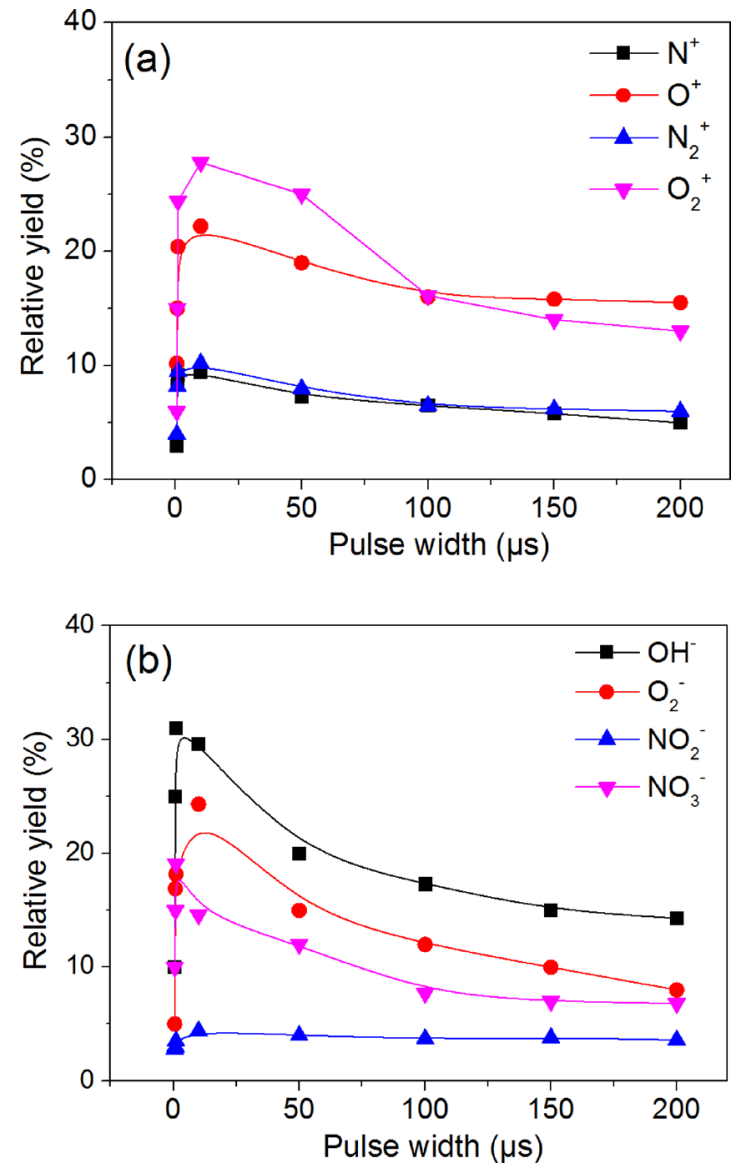

FIG. 7. The effect of the PW on the number density of positive ions for $\mathrm{N}^{+}$, $\mathrm{O}^{+}, \mathrm{N}_{2}{ }^{+}$, and $\mathrm{O}_{2}{ }^{+}$(a) and negative ions for $\mathrm{OH}^{-}, \mathrm{O}_{2}{ }^{-}, \mathrm{NO}_{2}^{-}$, and $\mathrm{NO}_{3}{ }^{-}$(b).

these species in gaseous and liquid phases have been linked to biomedical effects such as bacteria inactivation and cancer cell destruction. ${ }^{1,2,4,8}$ To confirm how the He plasma jet system generates some reactive species in deionized water, we measure the concentrations of $\mathrm{H}_{2} \mathrm{O}_{2}, \mathrm{NO}_{2}{ }^{-}$, and $\mathrm{NO}_{3}{ }^{-}$in water exposed to plasma jet under different PWs, and the results are shown in Fig. 8. It is shown that the $\mathrm{H}_{2} \mathrm{O}_{2}$ concentration in water almost increases linearly with the rising PW. It is well known that the $\mathrm{OH}$ is typically the main contributor to $\mathrm{H}_{2} \mathrm{O}_{2}$ production in both the gas and liquid phases, ${ }^{21,34}$

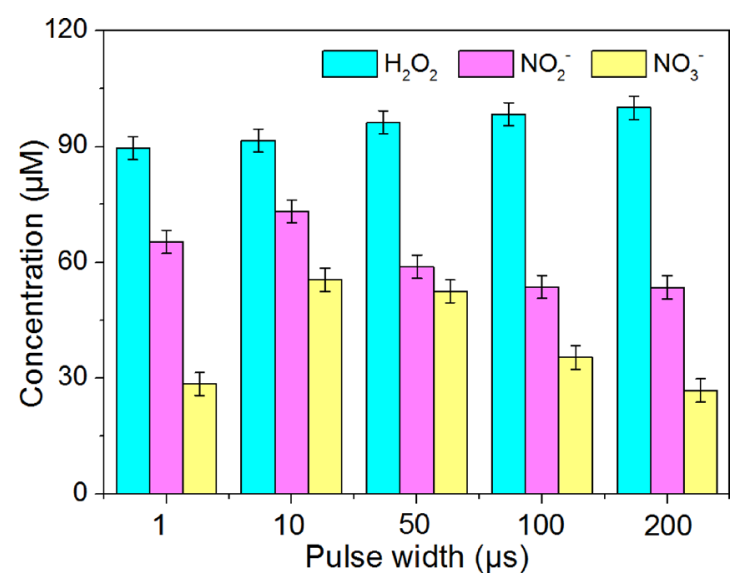

FIG. 8. The effect of PW on the concentrations of $\mathrm{H}_{2} \mathrm{O}_{2}, \mathrm{NO}_{2}{ }^{-}$, and $\mathrm{NO}_{3}{ }^{-}$in deionized water treatment by He plasma jet at different PWs. 
while the concentrations of $\mathrm{NO}_{2}{ }^{-}$and $\mathrm{NO}_{3}{ }^{-}$in water display the first increasing and then decreasing trends, which are similar to the trends of $\mathrm{NO}_{2}{ }^{-}$and $\mathrm{NO}_{3}{ }^{-}$concentration in the gas phase in Fig. 7(b).

To dissect the correlation of RONS in the gas and liquid phases, the origins of $\mathrm{H}_{2} \mathrm{O}_{2}, \mathrm{NO}_{2}^{-}$, and $\mathrm{NO}_{3}^{-}$production in water are investigated further. For $\mathrm{H}_{2} \mathrm{O}_{2}$ production, there are three pathways. First, $\mathrm{OH}$ radicals are produced though traditional electron impact ionization of $\mathrm{H}_{2} \mathrm{O}$ molecular. $\mathrm{OH}$ combines with other $\mathrm{OH}$ for $\mathrm{H}_{2} \mathrm{O}_{2}$ production in both the gas and liquid phases. ${ }^{31-34}$ Second, it is known when water is exposed to He plasma jet, a series of complex chemical reactions (listed in Table I) take place above the gas-liquid interface. The presence of water vapour entrained in discharge results in increased reactions with $\mathrm{H}_{2} \mathrm{O}$. Positive ions $\left(\mathrm{N}_{2}{ }^{+}\right.$ and $\mathrm{O}_{2}{ }^{+}$) produced in the gas phase react with $\mathrm{H}_{2} \mathrm{O}$, producing many $\mathrm{OH}$ radicals as in a series of chemical reactions from (1) to (12). Meanwhile, a large number of hydronium ions $\left(\mathrm{H}_{3} \mathrm{O}^{+}\right)$are formed as well as heavier ion water clusters $\left(\mathrm{H}_{3} \mathrm{O}^{+}\left(\mathrm{H}_{2} \mathrm{O}\right)_{n}\right) .{ }^{35}$ Third, negative ions $\mathrm{HO}_{2}{ }^{-}$and their water clusters $\left(\mathrm{HO}_{2}^{-}\left(\mathrm{H}_{2} \mathrm{O}\right)_{n}\right)$ dissolve into water, and then are quickly converted to other species. ${ }^{36,37}$ For example, $\mathrm{HO}_{2}{ }^{-}$is the conjugate base of $\mathrm{H}_{2} \mathrm{O}_{2}$, and in an acidic environment, it can lead to additional $\mathrm{H}_{2} \mathrm{O}_{2}$ production. For the $\mathrm{NO}_{2}{ }^{-}$and $\mathrm{NO}_{3}{ }^{-}$production in water, on one hand, they originate from $\mathrm{NO}_{2}{ }^{-}$and $\mathrm{NO}_{3}{ }^{-}$ions in the gas phase. The $\mathrm{NO}_{2}^{-}$and $\mathrm{NO}_{3}{ }^{-}$ are the dominant negative ions that transport into water when the water is exposed to He plasma jet. ${ }^{31}$ On the other hand, the $\mathrm{NO}, \mathrm{NO}_{2}$, and $\mathrm{N}_{2} \mathrm{O}_{5}$ in gas phase are also capable of reaching the gas-liquid interface and transported into water to form the aqueous $\mathrm{NO}_{2}^{-}$and $\mathrm{NO}_{3}{ }^{-}$though complex chemical reactions from (13) to (18). The other negative ions are oxygen molecules such as $\mathrm{O}^{-}, \mathrm{O}_{2}^{-}$, and $\mathrm{O}_{3}^{-}$, indicating

TABLE I. The chemical reactions from plasma above water surface and in water.

\begin{tabular}{|c|c|c|}
\hline No. & Chemical reactions & Refs. \\
\hline (1) & $\mathrm{N}_{2}+\mathrm{e}^{-} \rightarrow \mathrm{N}_{2}^{+}+2 \mathrm{e}^{-}$ & 29 \\
\hline (2) & $\mathrm{N}_{2}^{+}+\mathrm{H}_{2} \mathrm{O} \rightarrow \mathrm{N}_{2} \mathrm{H}^{+}+\mathrm{OH}$ & 32 \\
\hline (3) & $\mathrm{N}_{2}^{+}+\mathrm{H}_{2} \mathrm{O} \rightarrow \mathrm{H}_{2} \mathrm{O}^{+}+\mathrm{N}_{2}$ & 32 \\
\hline (4) & $\mathrm{N}_{2} \mathrm{H}^{+}+\mathrm{H}_{2} \mathrm{O} \rightarrow \mathrm{H}_{3} \mathrm{O}^{+}+\mathrm{N}_{2}$ & 33 \\
\hline (5) & $\mathrm{H}_{2} \mathrm{O}^{+}+\mathrm{O}_{2} \rightarrow \mathrm{O}_{2}^{+}+\mathrm{H}_{2} \mathrm{O}$ & 33 \\
\hline (6) & $\mathrm{H}_{2} \mathrm{O}^{+}+\mathrm{H}_{2} \mathrm{O} \rightarrow \mathrm{H}_{3} \mathrm{O}^{+}+\mathrm{OH}$ & 33 \\
\hline (7) & $\mathrm{H}_{3} \mathrm{O}^{+}+\mathrm{H}_{2} \mathrm{O}+\mathrm{M} \rightarrow \mathrm{H}_{3} \mathrm{O}^{+}\left(\mathrm{H}_{2} \mathrm{O}\right)+\mathrm{M}$ with $\mathrm{M}=\mathrm{N}_{2}, \mathrm{O}_{2}$ & 33 \\
\hline (8) & $\mathrm{O}_{2}+\mathrm{e}^{-} \rightarrow \mathrm{O}_{2}^{+}+2 \mathrm{e}^{-}$ & 32 \\
\hline (9) & $\mathrm{O}_{2}^{+}+\mathrm{H}_{2} \mathrm{O}+\mathrm{M} \rightarrow \mathrm{O}_{2}^{+}\left(\mathrm{H}_{2} \mathrm{O}\right)+\mathrm{M}$ with $\mathrm{M}=\mathrm{N}_{2}, \mathrm{O}_{2}$ & 33 \\
\hline (10) & $\begin{aligned} \mathrm{O}_{2}^{+}\left(\mathrm{H}_{2} \mathrm{O}\right) & +\mathrm{H}_{2} \mathrm{O} \rightarrow \mathrm{H}_{3} \mathrm{O}^{+}+\mathrm{OH}+\mathrm{O}_{2} \\
& \rightarrow \mathrm{H}_{3} \mathrm{O}^{+}(\mathrm{OH})+\mathrm{O}_{2}\end{aligned}$ & 33 \\
\hline (11) & $\mathrm{H}_{3} \mathrm{O}^{+}(\mathrm{OH})+\mathrm{H}_{2} \mathrm{O} \rightarrow \mathrm{H}_{3} \mathrm{O}^{+}\left(\mathrm{H}_{2} \mathrm{O}\right)+\mathrm{OH}$ & 33 \\
\hline (12) & $\mathrm{e}^{-}+\mathrm{H}_{2} \mathrm{O}+\mathrm{M} \rightarrow \mathrm{H}_{2} \mathrm{O}^{-}+\mathrm{M}$ & 35 \\
\hline (13) & $\mathrm{O}_{3}+\mathrm{NO}_{2}^{-} \rightarrow \mathrm{O}_{3}+\mathrm{NO}_{3}^{-}$ & 22 \\
\hline (14) & $2 \mathrm{NO}+2 \mathrm{HO}_{2} \rightarrow \mathrm{ONOOH} \rightarrow \mathrm{H}^{+}+\mathrm{NO}_{3}^{-}$ & 22 \\
\hline (15) & $\mathrm{NO}_{2}+\mathrm{O}_{2}^{-} \rightarrow \mathrm{O}_{2}+\mathrm{NO}_{2}^{-}$ & 22 \\
\hline (16) & $\mathrm{NO}_{3}+\mathrm{HO}_{2} \rightarrow \mathrm{NO}_{3}^{-}+\mathrm{H}^{+}+\mathrm{O}_{2}$ & 22 \\
\hline (17) & $\mathrm{NO}_{2}+\mathrm{OH} \rightarrow \mathrm{NO}_{3}^{-}+\mathrm{H}^{+}$ & 22 \\
\hline (18) & $\mathrm{N}_{2} \mathrm{O}_{5}+\mathrm{H}_{2} \mathrm{O} \rightarrow 2 \mathrm{NO}_{3}^{-}+2 \mathrm{H}^{+}$ & 22 \\
\hline (19) & $\mathrm{e}^{-}+2 \mathrm{O}_{2}^{-} \rightarrow \mathrm{O}+\mathrm{O}^{-}+\mathrm{O}_{2}$ & 22 \\
\hline (20) & $\mathrm{e}^{-}+\mathrm{H}_{2} \mathrm{O}+\mathrm{O}_{2} \rightarrow \mathrm{H}_{2}+\mathrm{O}^{-}+\mathrm{O}_{2}$ & 22 \\
\hline (21) & $\mathrm{O}+\mathrm{O}^{-}+\mathrm{O}_{2} \rightarrow \mathrm{O}_{3}^{-}+\mathrm{O}$ & 22 \\
\hline
\end{tabular}

that the main pathway of creation is through dissociative electron attachment of $\mathrm{O}_{2}$ and subsequent oxidization to form many of the negative ion species, as shown in the reaction from (19) to (21) in Table I.

In general, although mass spectrometry is so sensitive that it can detect very small quantities of gaseous ions, the observation shows that the concentrations of RONS generated by the plasma in the gas phase or at the gas-liquid interface are sufficiently high that they can affect the chemical nature of water that was exposed to the plasma. ${ }^{38}$ The mass spectrometry data obtained in our study show that all dominant ion species generated by the plasma jet system contain either oxygen or nitrogen $\left(\mathrm{N}^{+}, \mathrm{O}^{+}, \mathrm{N}_{2}^{+}, \mathrm{O}_{2}^{+}, \mathrm{OH}^{-}, \mathrm{O}_{2}^{-}\right.$, $\mathrm{NO}_{2}{ }^{-}, \mathrm{NO}_{3}{ }^{-}$), which suggests that the plasma generates a large amount of RONS. However, when plasma jet is applied to a wet surface (such as living tissues) or treated liquid, there is mainly ion water clusters formed near the surface. Additionally, there are many short-lived species $\left(\mathrm{OH}, \mathrm{O}_{2}{ }^{-}\right)$ and long-lived species $\left(\mathrm{H}_{2} \mathrm{O}_{2}, \mathrm{NO}_{2}^{-}\right.$, and $\left.\mathrm{NO}_{3}^{-}\right)$in the liquid. ${ }^{39}$ It is believed that the water cluster formation (hydration process) at the gas-liquid interface can help us obtain more information about the correlation of RONS between in the gas phase and the liquid phase.

\section{CONCLUSIONS}

In this paper, we studied the effects of the PW from $0.5 \mu$ s to $200 \mu$ s on the discharge characteristics of a plasma jet, with particular focus on the production and correlation of the ROS/RNS in gas- and liquid-phase, and the RONS are measured by OES, mass spectrometer, and microplate reader, respectively, for the purpose of analyzing and elucidating the correlation of RONS transported from gas phase into liquid phase. It is found that the length of plasma jet plume first increases before the PW of $10 \mu$ s, then gradually decreases, and finally becomes almost unchanged beyond $150 \mu \mathrm{s}$; this is mainly ascribed to the accumulation of space charges that lead to weakening of the reduced electric field with an increase of PW. Additionally, it is found that the excited reactive species, the positive and negative ions from plasma jet, and the concentrations of $\mathrm{NO}_{2}^{-}$and $\mathrm{NO}_{3}{ }^{-}$in deionized water exposed to plasma jet also display the first increasing and then decreasing change trend with increase of PW. However, the concentration of $\mathrm{H}_{2} \mathrm{O}_{2}$ in water increases almost linearly with the rising of $\mathrm{PW}$, which is mainly attributed to the formation of the $\mathrm{H}_{3} \mathrm{O}^{+}$and $\mathrm{HO}_{2}^{-}$, as well as their ion water clusters that can produce more $\mathrm{OH}$ radicals to be converted into $\mathrm{H}_{2} \mathrm{O}_{2}$. The above results indicate that the water clusters generated by the plasma in the gas phase or at the gas-liquid interface are sufficiently high that they can affect the chemical nature and dose of aqueous RONS in water exposed to the plasma.

\section{ACKNOWLEDGMENTS}

This work was supported by the National Natural Science Foundation of China (Grant Nos. 51707150 and 51521065), the China Postdoctoral Science Foundation (2017M613134 and 2017M610639), the Shaanxi Province Postdoctoral Science Foundation (2017BSHYDZZ11), and 
the State Key Laboratory of Electrical Insulation and Power Equipment (Grant Nos. EIPE 14123 and EIPE 17309).

${ }^{1}$ D. B. Graves, Plasma Process Polym. 11, 1120-1127 (2014).

${ }^{2}$ P. Lukes, E. Dolezalova, I. Sisrova, and M. Clupek, Plasma Sources Sci. Technol. 23, 015019 (2014).

${ }^{3}$ S. A. Norberg, E. Johnsen, and M. J. Kushner, Plasma Sources Sci. Technol. 24, 035026 (2015)

${ }^{4}$ M. G. Kong, G. Kroesen, G. Morfill, T. Nosenko, T. Shimizu, J. Van Dijk, and J. L. Zimmermann, New J. Phys. 11, 115012 (2009).

${ }^{5}$ X. Lu, Z. Jiang, Q. Xiong, Z. Tang, X. Hu, and Y. Pan, Appl. Phys. Lett. 92, 081502 (2008)

${ }^{6}$ X. Lu, G. V. Naidis, M. Laroussi, and K. Ostrikov, Phys. Rep. 540, 123-166 (2014).

${ }^{7}$ Z. J. Liu, D. H. Xu, D. X. Liu, Q. J. Cui, H. F. Cai, Q. S. Li, H. L. Chen, and M. G. Kong, J. Phys. D: Appl. Phys. 50, 195204 (2017).

${ }^{8}$ D. T. EIg, I. W. Yang, and D. B. Graves, J. Phys. D: Appl. Phys. 50, 475201 (2017).

${ }^{9}$ G. Uchida, S. Uchida, H. Kajiyama, and T. Shinoda, J. Appl. Phys. 107, 023305 (2010).

${ }^{10}$ G. Uchida, K. Takenaka, and Y. Setsuhara, J. Appl. Phys. 117, 153301 (2015).

${ }^{11}$ S. J. Kim and T. H. Chung, IEEE Trans. Plasma Sci. 39, 2280 (2011).

${ }^{12}$ E. Robert, V. Sarron, D. Ries, S. Dozias, M. Vandamme, and J. M. Pouvesle, Plasma Sources Sci. Technol. 21, 034017 (2012).

${ }^{13}$ J. L. Walsh, P. Olszewski, and J. W. Bradley, Plasma Sources Sci. Technol. 21, 034007 (2012).

${ }^{14}$ Q. Xiong, X. Lu, Y. Xian, J. Liu, C. Zou, Z. Xiong, W. Gong, K. Chen, X. Pei, F. Zou, J. Hu, Z. Jiang, and Y. Pan, J. Appl. Phys. 107, 073302 (2010).

${ }^{15}$ X. Lu, Z. Jiang, and Q. Xiong, IEEE Trans. Plasma Sci. 36, 988 (2008).

${ }^{16}$ H. M. Joh, J. Y. Choi, S. J. Kim, T. H. Kang, and T. H. Chung, AIP Adv. 7(8), 085106 (2017)

${ }^{17}$ G. Uchida, K. Takenaka, and Y. Setsuhara, Jpn. J. Appl. Phys., Part 1 55, 01AH03 (2016).

${ }^{18}$ K. C. Hsieh, R. J. Wandell, S. Bresch, and B. R. Locke, Plasma Process Polym. 14, 1600171 (2017).

${ }^{19}$ D. B. Graves, Phys. Plasmas 21, 080901 (2014).
${ }^{20}$ E. J. Baek, H. M. Joh, S. J. Kim, and T. Chung, Phys. Plasmas 23, 073515 (2016).

${ }^{21}$ D. X. Liu, Z. C. Liu, C. Chen, A. J. Yang, D. Li, M. Z. Rong, H. L. Chen, and M. G. Kong, Sci. Rep. 6, 23737 (2016).

${ }^{22}$ Z. C. Liu, D. X. Liu, C. Chen, D. Li, A. J. Yang, M. Z. Rong, H. L. Chen, and M. G. Kong, J. Phys. D: Appl. Phys. 48, 495201 (2015).

${ }^{23}$ M. Z. Rong, W. J. Xia, X. H. Wang, Z. J. Liu, D. X. Liu, Z. H. Liang, X. N. Zhang, and M. G. Kong, Appl. Phys. Lett. 111, 074104 (2017).

${ }^{24}$ Y. Xian, P. Zhang, X. P. Lu, X. K. Pei, S. Q. Wu, Q. Xiong, and K. Ostrikov, Sci. Rep. 3, 1599 (2013).

${ }^{25}$ C. Zhang, T. Shao, Y. Zhou, Z. Fang, P. Yan, and W. Yang, Appl. Phys. Lett. 105, 044102 (2014).

${ }^{26}$ P. Bruggeman, F. Iza, D. Lauwers, and Y. Aranda-Gonzalvo, J. Phys. D: Appl. Phys. 43, 012003 (2010)

${ }^{27}$ J. S. Oh, Y. Aranda-Gonzalvo, and J. W. Bradley, J. Phys. D: Appl. Phys. 44, 365202 (2011).

${ }^{28}$ M. Sabo, J. Páleník, M. Kučera, H. Han, H. Wang, Y. Chu, and S. Matejčík, Int. J. Mass Spectrom. 293, 23 (2010).

${ }^{29}$ K. McKay, J. S. Oh, J. L. Walsh, and J. W. Bradley, J. Phys. D: Appl. Phys. 46, 464108 (2013).

${ }^{30}$ T. Martensa and A. Bogaerts, Appl. Phys. Lett. 92, 041504 (2008).

${ }^{31}$ T. Ito, K. Gotch, K. Sekimoto, and S. Hamaguchi, Plasma Med. 5, 283 (2015).

${ }^{32}$ M. Pavlik and J. D. Skalny, Rapid Commun. Mass Spectrom. 11, 1757 (1997).

${ }^{33}$ V. G. Anicich, J. Phys. Chem. Ref. Data 22, 1469 (1993).

${ }^{34}$ T. Miura, A. Ando, K. Hirano, C. Ogura, T. Kanazawa, M. Ikeguchi, A. Seki, S. Nishihara, and S. Hamaguchi, J. Phys. D: Appl. Phys. 47, 445402 (2014).

${ }^{35}$ C. A. J. vanGiles, S. Hofmann, and B. K. H. L. Boekema, J. Phys. D: Appl. Phys. 46, 175203 (2013).

${ }^{36}$ J. D. Skalny, T. Mikoviny, S. Matejcik, and N. J. Mason, Int. J. Mass Spectrom. 233, 317 (2004).

${ }^{37}$ K. Sekimoto and M. Takayama, Int. J. Mass Spectrom. 46, 50 (2011).

${ }^{38}$ E. Stoffels, Y. Aranda Gonzalvo, T. D. Whitmore, D. L. Seymour, and J. A. Rees, Plasma Sources Sci. Technol. 16, 549 (2007).

${ }^{39}$ J. D. Skalny, J. Orszagh, N. J. Mason, J. A. Rees, Y. Aranda-Gonzalvo, and T. D. Whitmore, Int. J. Mass Spectrom. 272, 12 (2008). 